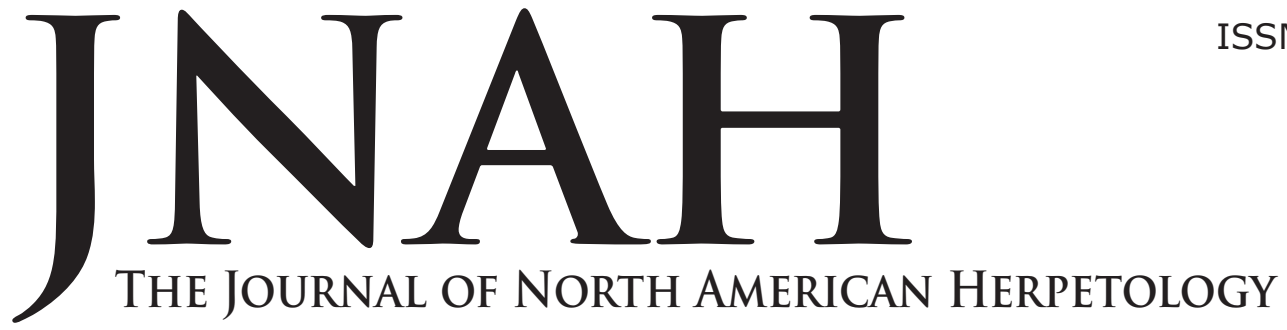

ISSN 2333-0694

Volume 2021, Number 1

June 2021

journals.ku.edu/jnah

\title{
THE NATURAL HISTORY OF THE NORTHERN BLACK RACER (COLUBER CONSTRICTOR CONSTRICTOR) IN SOUTH-CENTRAL PENNSYLVANIA
}

\author{
JASON DALLAS ${ }^{1,2}$, WALTER E. MESHAKA, JR. ${ }^{3}$, AND PABLO R. DELIS ${ }^{1}$ \\ ${ }^{1}$ Department of Biology, Shippensburg University, 1871 Old Main Drive, Shippensburg, PA 17257. \\ USA. \\ ${ }^{2}$ Department of Biological Sciences, Southern Illinois University, 1125 Lincoln Drive, Carbondale, IL \\ 62901. USA. \\ ${ }^{3}$ Section of Zoology and Botany, State Museum of Pennsylvania, 300 North Street, Harrisburg, PA \\ 17120. USA. \\ Corresponding author: Jason Dallas; dallasjason2@gmail.com; 215-870-9356
}

\begin{abstract}
Long-term species surveys are effective tools for identifying changes in population demography which is of particular importance for those in threatened habitats such as grasslands. Due to their cryptic nature, snakes can benefit greatly from these types of surveys but multiyear surveys for snakes are rare in Pennsylvania and the surrounding region. We conducted coverboard surveys of the grassland specialist Northern Black Racer (Coluber constrictor constrictor) over eight years separated into two sampling periods (2008-2012 and 2015-2017) across a habitat-mosaic in south-central Pennsylvania. We recorded information on their body size, demography, and monthly activity. We compared these traits between the sampling periods to determine how they vary over time. A total of 70 Northern Black Racers were captured during this project. As expected, grasslands were heavily exploited by Northern Black Racers highlighting their importance to this species. There was a shift from relatively larger-bodied, older individuals towards relatively smaller-bodied, younger individuals between the sampling periods, but the sex ratio remained unchanged. Monthly activity of adults was unimodal in both sampling periods, but the month of peak activity varied and there was a possible effect of precipitation on this difference. The change in age structure between the sampling periods suggested that a widespread mortality event, possibly from exceedingly cold overwintering conditions, may have culled older individuals resulting in a younger cohort to fill the void. As Northern Black Racers are an important grassland predator, our data show the benefits of long-term surveys through detecting changes in demography that could potentially influence long-term survival of a population.
\end{abstract}

Key Words: Coluber constrictor, Natural history, Grasslands, Overwintering

\section{INTRODUCTION}

Grassland habitats are home to a diverse array of flora and fauna and are essential to the survival of many species (Yahner 2003, Wilson et al. 2012). However, widespread habitat degradation from multiple sources (Wick et al. 2016) has resulted in large-scale declines of grassland birds (Brennan and Kuvlesky 2005, Rosenberg et al. 2019), insects (Sánchez-Bayo and Wyckhuys 2019), reptiles (Gibbons et al. 2000, Todd et al. 2010), and vegetation (Ratajczak et al. 2012). Similar patterns of habitat and species declines have also been observed in Pennsylvanian vertebrates (Yahner 2003). One particular group of animals that inhabits grasslands extensively is reptiles - particularly snakes - due to the thermal qualities these habitats provide in comparison to forests (Blouin-Demers and Weatherhead 2001, Row and Blouin-Demers 2006, Carfagno et al. 2016, Halliday and Blouin-Demers 2016). Despite these strong links, snakes have received relatively less attention when compared to other grassland vertebrates and there remains a great need for monitoring their population health and local ecology.

The Northern Black Racer (Coluber constrictor constrictor, Linnaeus 1758) is a subspecies of the North American Racer (Auffenberg 1955, Burbrink et al. 2008) which is a slender but large-bodied colubrid. Their geographic range extends from southern Maine to northern Georgia and westward to central Kentucky and eastern Ohio (Powell et al. 2016). They occur in every Pennsylvania county 
but their occupancy is dependent on the availability of large patches of open habitats (Hulse et al. 2001, Kjoss and Livaitis 2001a, Meshaka et al. 2009). The dietary breadth of Northern Black Racers is the largest among northeastern snakes and they are the prominent ophiophagous species in the northern part of their range (Surface 1906, Klimstra 1959, Klemens 1993, Palmer 1995). As a result of their ophiophagous nature, large grassland patches can become dominated by Northern Black Racers through predatory exclusion of smaller-bodied snakes and persistence of larger-bodied individuals of remaining species (Meshaka et al. 2009, Meshaka and Delis 2014; but see Kjoss and Livaitis 2001a). This predatory effect on co-occurring snakes makes Northern Black Racers an important species to study to better understand the population dynamics in grassland patches.

Despite being a common species throughout Pennsylvania (Hulse et al. 2001), field research on the natural history of the Northern Black Racer remains elusive in the state. The primary objective of this study was to further explore the life history and ecology of Northern Black Racers in fragmented grasslands in south-central Pennsylvania over eight sampling seasons in ten years. We also wanted to identify if body size, monthly activity, and population demographics were influenced by sampling period. The broad goal of this study is to better understand the demography of an important wide-foraging predator and prey species in northeastern grasslands.

\section{MATERIALS AND METHODS}

\section{Research-Site Description}

Letterkenny Army Depot (LEAD; 40.014ㅇ․ -77.705) is a military facility located in Chambersburg, Franklin County, Pennsylvania. The facility encompasses nearly 7200 ha with restricted public access, but approved field studies can be conducted with limited human interruption. Temperatures within the region average $22.3^{\circ} \mathrm{C}$ and $0^{\circ} \mathrm{C}$ in the summer and winter, respectively, and it receives a mean annual rainfall of approximately $101.8 \mathrm{~cm}$ (The Pennsylvania State Climatologist). Our study took place across 15 specifically targeted sites in Zone II (Fig. 1), an 1800 ha portion of LEAD located at the base of

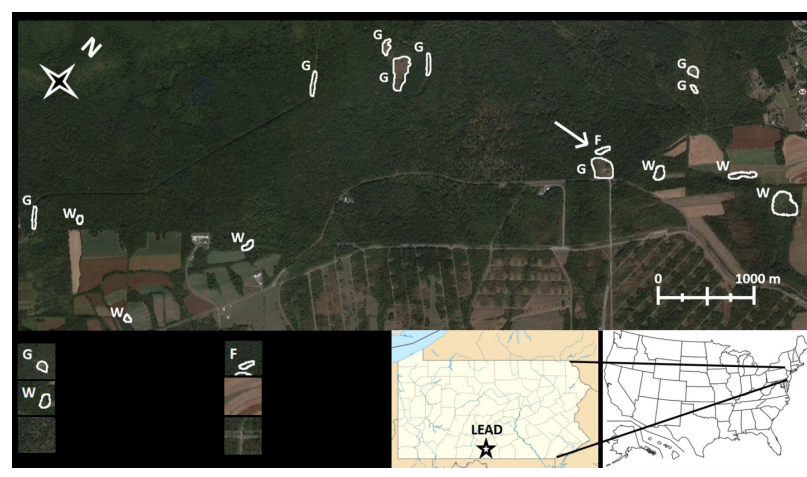

Fig. 1. Aerial photograph showing the 15 specific sampling locations at Letterkenny Army Depot (LEAD), PA. Habitat designations were based on prior research gathered from 2008 to 2012, historic evidence, and habitat composition, with forest being the dominant habitat. Habitats are defined as grassland $(G)$, forest (F), and wetland (W). The forest site denoted with an arrow was grouped with grassland sites due to its close proximity to a grassland site. Star symbol = Specific location of LEAD within Pennsylvania major waterways and county outlines. Modified from Google Earth satellite imagery from 2015.
North Mountain in the Blue Mountain range. These sites were a combination of forested, wetlands, and grassland sites across a landscape dominated by temperate deciduous forest. More detailed descriptions of the LEAD's vegetation and these specific sampling sites are provided elsewhere (Delis et al. 2010, Meshaka and Delis 2014, Dallas 2017). Zone II is subjected to a variety of human activities and disturbances, primarily agriculture, selective logging, and controlled hunting, which makes our findings applicable to resource management practices of the state.

\section{Data Collection}

Data were collected from April to October 2008-2012, 2015, and 2016 and were also collected in April, June, and July 2017 using a combination of monthly coverboard sampling and opportunistic surveys. The coverboards used were $1.0-1.2 \times 2.0-2.5 \mathrm{~m}$ sheets of corrugated metal. Coverboards are effective at detecting Northern Black Racers (Grant et al. 1992, Meshaka et al. 2009) and have shown generally equal usage amongst all size classes (Kjoss and Livaitis 2001b, Gregory and Tuttle 2016). All coverboards were checked for Northern Black Racers in a systematic fashion every month, and opportunistic surveys of natural cover objects (e.g., logs, rocks, shrubs) occurred simultaneously.

Upon capture, measurement of snout-vent length (SVL) to the nearest $0.1 \mathrm{~cm}$ was taken. The SVL was used to approximate ontogenetic stage (juvenile and adult) as Hulse et al. (2001) defined $70.0 \mathrm{~cm}$ as the size sexual maturity was achieved; although we observed smaller individuals engaged in copulation and classified them as adults. Sex of the individual was determined by tail morphology and/or eversion of the hemipenes through gentle pressure at the base of the tail. Presence and number of eggs was determined through light palpation of the ventral surface caudal to the body midpoint. All Northern Black Racers were marked using a Passive Integrated Transponder (PIT) tag (Biomark ${ }^{\circledR}$, Boise, Idaho) subcutaneously which provided each snake with a unique ID number so that individuals could be easily and accurately identified upon recapture. Individuals that were too small for subcutaneous PIT tags were given a cohort mark in the form of a ventral scale clip. The health of captured individuals was assessed by external examination for the presence of lesions, ectoparasites, and other observable maladies. All snakes were released after being processed under the same coverboard they were captured with the entire process taking less than five minutes.

\section{Data Analyses}

A linear model was used to identify if Northern Black Racer SVL was influenced by sampling period (20082012 v. 2015-2017), sex, and the interaction. Significant results were assessed via Tukey's honest significant difference post-hoc tests to determine significance among group differences. A two-sample t-test determined if SVL influenced if individuals were recaptured. Only the SVL recorded from initial capture was used in body size analyses to reduce pseudoreplication of including the same individual multiple times. We used $X^{2}$ goodness-of-fit tests to compare the sex and age ratios between the sample periods and habitat types [grassland $(\mathrm{N}=9)$ or non-grassland $(N=6)$ ]. Monthly activity of adults was compared between sampling periods while the low number of juveniles resulted in using all years for examining activity with $x^{2}$ goodness-of-fit tests. Monthly activity incorporated both new and recaptured individuals, so it 
was possible for an individual to be counted more than once both within and among years. The alpha value for all analyses was set to 0.05 . All analyses were conducted using R version 3.6.1 (R Development Core Team, 2019).

\section{RESULTS}

\section{Captures}

Over the eight sampling years, 70 Northern Black Racers were captured and given a unique PIT tag ID with 42 and 28 collected during 2008-2012 and 2015-2017, respectively. From the combined sample, 25 individuals were recaptured between one and four times. Additionally, five individuals were captured but not provided a PIT tag, two hatchlings were given cohort marks, and 11 individuals were observed but eluded capture. The majority of captures occurred at grasslands or other open-habitat types $(\mathrm{N}=61)$ and all recapture events occurred these habitats.

\section{Sex Ratio}

The adult sex ratios did not differ between the sample periods $\left(X^{2}=0.039\right.$, $\left.d f=1, P=0.84\right)$, with both periods exhibiting male-biased populations: 2008-2012 = $1.2: 1.0(\mathrm{~N}=40), 2015-2017=1.3: 1.0(\mathrm{~N}=21)$. Across all sampling years, the sex ratio of adults captured only a single time were male-biased 1.5:1.0 ( $\mathrm{N}=33)$ while those recaptured were slightly female-biased $0.8: 1.0$ (N $=22)$, yet this difference was not significant $\left(X^{2}=2.12\right.$, $\mathrm{df}=1, \mathrm{P}=0.15)$. The low number of adults $(\mathrm{N}=3)$ in non-grassland habitats constrained our ability to test for habitat effects on the sex ratio. Juveniles also showed a non-significant male-bias $\left(2.3: 1.0, \mathrm{~N}=13 ; \mathrm{X}^{2}=1.92\right.$, df $=1, \mathrm{P}=0.17$ ).

\section{Age Ratio}

Adults were more prevalent at LEAD, but sampling period did not influence the age ratio $\left(X^{2}=2.49\right.$, $\mathrm{df}=$ $1, P=0.11$ ) despite adults being nearly twice as likely to be encountered during 2008-2012 (5.0:1.0, $\mathrm{N}=$ 48) than 2015-2017 (2.6:1.0; N = 29). An ontogenetic component to habitat association was detected in this sample. The relative proportion of juveniles was greater in non-grassland habitats $(0.6: 1.0, \mathrm{~N}=8)$ than in grasslands (5.3:1.0; $\left.N=69 ; \mathrm{X}^{2}=63.82, \mathrm{df}=1, \mathrm{P}<0.0001\right)$ but the small sample size in the former group may skew this finding.

\section{Body Sizes}

During the first sampling period of 2008-2012, adults

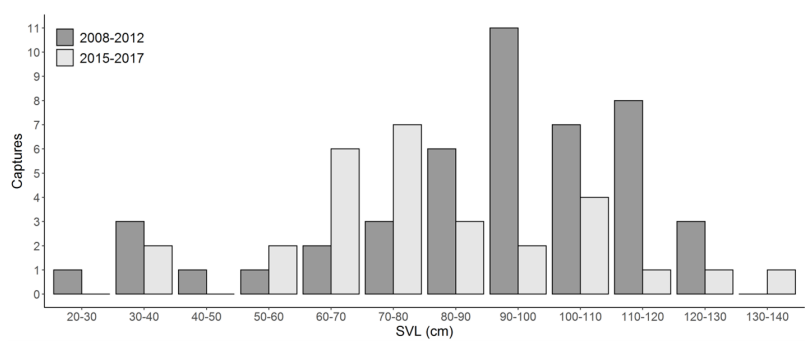

Fig. 2. Body size represented as snout-vent-length (SVL) for the Northern Black Racer, Coluber constrictor constrictor, found at sites in Letterkenny Army Depot, PA, during 2008-2011, (Meshaka and Delis 2014), 2012 (W. M. Meshaka and P. R. Delis unpub. data), and 2015-2017 (this study). Data shown excludes all recaptured individuals. measuring between $90-120 \mathrm{~cm}$ SVL were the most frequently encountered while young adults between 60-80 $\mathrm{cm}$ SVL were commonly found during 2015-2017 (Fig. 2). Two individuals captured in 2009 (a male and female) were removed as their SVL may have been misreported and represented outliers. Consequently, the body size of adults differed between sampling periods (Fig. $3 ; F_{1,55}=$ $5.66, P=0.021)$, and the interaction between sampling period and sex approached significance $\left(F_{1,55}=3.20\right.$, $P=0.079$ ). A post-hoc analysis revealed that the only statistically significant difference was that males during 2008-2012 ( $\mathrm{N}=21 ; 105.9 \pm 3.1 \mathrm{~cm} ; 73.0-129.5)$ were larger than those during 2015-2017 ( $\mathrm{N}=12,88.4 \pm 5.3$ $\mathrm{cm} ; 65.0-130.0$ ) (Fig. 3; $\mathrm{P}=0.022$ ). Furthermore, adult body size did not influence if an individual was recaptured or caught only once $\left(t_{51}=0.0025, P=1.0\right)$.

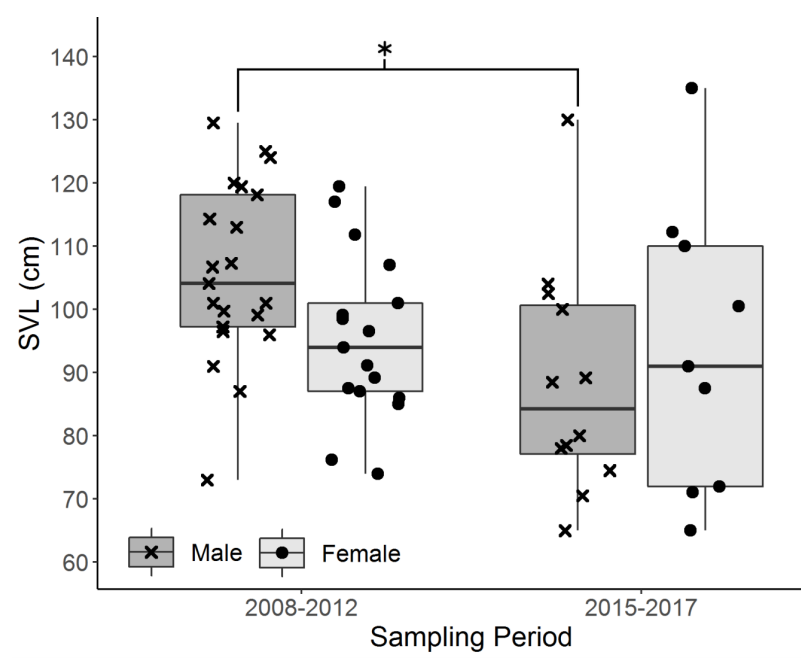

Fig. 3. Sexual size dimorphism represented as snout-ventlength (SVL) of adult Northern Black Racers, Coluber constrictor constrictor, found at sites in Letterkenny Army Depot, PA, during 2008-2011, (Meshaka and Delis 2014), 2012 (W. M. Meshaka and P. R. Delis unpub. data), and 2015-2017 (this study). Data shown excludes all recaptured individuals. Boxplots denote the interquartile range with the center line as the mean, and whiskers represent $1.5 \mathrm{x}$ the upper or lower quartiles. Asterisk indicates significant difference between post hoc pairwise comparisons (Tukey's HSD test, $\mathrm{P}<0.05$ ).

\section{Monthly Activity}

Northern Black Racer monthly activity was unimodal regardless of sampling period $\left(X^{2}=45.80, d f=6, P<\right.$ 0.0001 ) but the peak activity differed between the two periods (Fig. 4). Incorporating all snake sightings, which included those that escaped capture and all recaptures, peak monthly activity during 2008-2012 occurred in May while June was the month of greatest activity during 2015-2017 ( $\left.X^{2}=17.82, d f=6, P=0.0067\right)$. While the monthly activity of adults was unimodal, juveniles exhibited no strong monthly distribution (Fig. $4 ; X^{2}=2.40$, df $=6, P=0.88$ ).

\section{Reproduction}

On 22 May 2015, we found a male and female together under a coverboard. Nine females were noted as gravid over all field seasons. Four instances occurred in both May and June, and a single gravid female was encountered in July. Gravid females ranged 87.0-152.4 cm SVL. From these nine females, the clutch size was palpated 


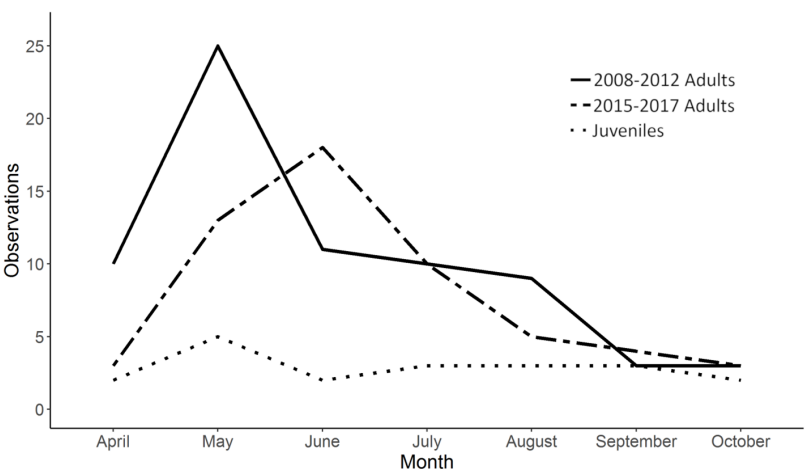

Fig. 4. Monthly activity of the Northern Black Racer, Coluber constrictor constrictor, found at sites in Letterkenny Army Depot PA, during 2008-2011, (Meshaka and Delis 2014), 2012 (W. M. Meshaka and P. R. Delis unpub. data), and 2015-2017 (this study). Data incorporate recaptures and individuals that were observed but escaped capture. Adult activity is separated by sampling period while juvenile activity was combined from both sampling periods.

for six individuals with an average of $12.0 \pm 0.82$ eggs (10-15). There was no evidence of a correlation between female SVL and clutch size ( $r=0.17, P>0.78)$.

\section{DISCUSSION}

This long-term monitoring project, based on 70 uniquely marked individuals, achieved its goal of furthering our understanding of Northern Black Racers, an open-habitat specialist, in Pennsylvania, and shed light on their population dynamics. The two distinct sampling periods (20082012 and 2015-2017) allowed for comparisons between observable changes in population demography and body size. Although adult sex ratios were similar across the sampling periods, the age ratio changed with a greater relative abundance of juveniles during 2015-2017; however the difference was not significant. Adult body size was also different between the sampling periods as adults were smaller during 2015-2017 than 2008-2012. Our data suggest that Northern Black Racers underwent a considerable change in population structure from one dominated by large, presumably older, adults towards one comprised of smaller, likely younger, adults and a greater juvenile presence, although the exact cause of this shift remains unknown.

Northern Black Racers were predominantly found in open habitats at LEAD which is in agreement with museum (Hulse et al. 2001) and field (Kjoss and Livaitis 2001a, Meshaka et al. 2009, Howey et al. 2016) data for this species. North American Racers have an energetically expensive foraging strategy that requires a consistently high metabolic rate (Plummer and Congdon 1996). This influences their need to exploit warm thermal habitats to achieve high operating body temperatures $\left(>29.5^{\circ} \mathrm{C}\right)$ (Brattstrom 1965, Kitchell 1969, Ernst et al. 2014) that maximize performance (Howey 2014). Because we did not assess the body or environmental temperatures of captured individuals, we cannot conclude that thermal requirements drove racer selection of open habitats. Despite evidence suggesting that the efficacy of behavioral thermoregulation of Northern Black Racers is relatively habitat-independent (Howey 2014), they were more abundant in open habitats (Howey et al. 2016) and we observed greater site fidelity as all recaptures occurred at these habitats. This suggests that the maintenance of grassland habitats is important to the long-term survival of Northern Black Racer populations.
While racers preferentially used grasslands, age structure differed between the two habitats with juveniles more commonly found at non-grassland habitats. Ontogenetic habitat shifts are not uncommon in reptiles (e.g., Stamps 1983, Keren-Rotem et al. 2006, Briggs 2012) but have not been previously described in racers. North American Racers are known to exhibit cannibalistic behaviors (Conant 1938, Hamilton and Pollack 1956, Fitch 1963, Rainwater et al. 2007) and we speculate that juvenile Northern Black Racers exploit non-grassland habitats as refugia from larger predatory conspecifics. Furthermore, upon reaching sexual maturity, young adults likely migrate to grasslands that support other mature adults improving their mating chances. This was evident as one juvenile that was initially captured at a wetland habitat in September 2016 was recaptured at a grassland habitat more than $1.7 \mathrm{~km}$ away the following summer. The small body size of juveniles limits the ability to track their movements via radiotelemetry indicating the need for long-term monitoring to confirm this behavior. Although occupying a disparate habitat would also reduce intraspecific competition among Northern Black Racers, Rosen (1991) noted that Blue Racers, C. c. foxii (Baird and Girard, 1853), exhibited ontogenetic diet partitioning with juveniles selecting smaller-bodied prey items compared to adults suggesting intraspecific competition is minimal. While grassland habitats are essential to the long-term survival of adult Northern Black Racers, neighboring non-grassland areas may also be necessary in maintaining stable recruitment numbers.

Across both sampling periods, the adult sex ratio was male-biased. Other North American Racer populations vary in their adult sex ratios, male-biased (Ernst et al. 2016), female-biased (Fitch 1963, Rosen 1991), and variable (Howey et al. 2016), suggesting these effects are location-specific. Juvenile racers in this study and that of Rosen (1991) were predominantly male suggesting clutches are skewed towards males. As recaptured individuals at LEAD were female-biased, it suggests that a male-biased sex ratio of clutches may offset the higher mortality risk male snakes face resulting from larger movements and home ranges (e.g., Klug et al. 2011, Martino et al. 2012; but see Carfagno and Weatherhead 2008). Collecting clutches and tracking the movements of adult Northern Black Racers at LEAD would serve as logical steps in determining what factors influence the adult sex ratios at this site.

The mean body sizes of adult Northern Black Racers at LEAD are in line with those described previously for Pennsylvania (Hulse et al. 2001), Virginia (Mitchell 1994, Ernst et al. 2016), Ohio (Howey et al. 2016), and Connecticut (Klemens 1993). However, there was a difference in adult body size between the sampling periods with those during 2008-2012 being larger on average than those during 2015-2017 (Fig. 3). This, along with relatively more juveniles found in the latter sampling period, was suggestive of a demographic shift towards an overall younger population during 2015-2017 (Fig. 2 ). The most parsimonious explanations for this change are that the larger, older individuals captured during 2008-2012 died due to aging and/or poor overwintering conditions caused widespread mortality within the population. High levels of overwintering mortality in snakes are linked to flooding (Gillingham and Carpenter 1978, Shine and Mason 2004) and/or low temperatures (Rosen 1991). Examining these climatic variables for NovemberMarch, the observed period of hibernation for Northern Black Racers, in south-central Pennsylvania (Region 4; 
The Pennsylvania State Climatologist) for both sampling periods and the years in between revealed that precipitation decreased over the years from $76.95 \mathrm{~mm}$ during 2007-2012 to $60.91 \mathrm{~mm}$ during 2012-2015 and 42.80 $\mathrm{mm}$ during 2015-2017. Temperatures also decreased from $2.31^{\circ} \mathrm{C}$ during $2007-2012$ to $0.71^{\circ} \mathrm{C}$ during $2012-$ 2015 but then rose to $4.12^{\circ} \mathrm{C}$ during 2015-2017 (The Pennsylvania State Climatologist). Additionally, the overwintering months of 2013-2014 and 2014-2015 were among the coldest $11 \%$ since 1900 for south-central Pennsylvania (The Pennsylvania State Climatologist). It is possible that unreliable and anomalous wintering conditions, possibly derived from climate change, are harming the physiological conditions of this species. Long-term studies in southern France demonstrated that micro-geographic environmental variation can generate qualitative shifts in actuarial senescence patterns in the Meadow Viper, Vipera ursinii, (Tully et al. 2020). This suggests that the colder temperatures during the winters between the sampling periods, which were abnormally cold and fell below the long-term winter average temperatures, may have caused widespread mortality among Northern Black Racers.

Hibernation is associated with widespread mortality in temperate snake species (Gillingham and Carpenter 1978, Shine and Mason 2004, Harvey and Weatherhead 2006). Shine and Mason (2004) found that a Red-sided Gartersnake, Thamnophis sirtalis parietalis (Say, 1823), population shifted towards a greater abundance of smaller size-classes in the years following a largescale overwintering mortality event. Our data compliment their findings and suggest that mortality associated with the overwintering period might have driven the observed shift towards a smaller, younger population in 2015-2017. We found the temperatures during the winters following the first sample period were abnormally cold for this region. These fluctuations and deviations from typical climate patterns may have resulted in substantial mortality as was documented in Blue Racers (Rosen 1991). Although overwintering mortality rates of Northern Black Racers have not been widely reported, they have been documented to be highly variable in Western Yellow-bellied Racers (C. c. mormon, Baird and Girard, 1852), ranging from 7\% (Brown and Parker 1984) to 50\% (Hirth 1966). While we are aware that our study did not specifically test these factors, our results suggest that climate change-generated overwintering anomalies may drive wholescale changes in population demographics.

Northern Black Racers at LEAD were active from April to October, with a unimodal peak in late-spring/early-summer and activity rapidly declining throughout the remainder of the year (Fig. 4). Similar activity periods have been found for Northern Black Racers throughout their range (Klemens 1993, Mitchell 1994, Palmer 1995, Hulse et al. 2001) with evidence for both unimodal (Palmer 1995) and bimodal (Mitchell 1994, Hulse et al. 2001) patterns. The largest peak in activity of adults coincides with the mating season, when males are actively seeking females during May and June (Conant 1938, Hulse et al. 2001) (Fig. 4). Our observation of copulatory behavior in late May explains the reason for the activity spike at LEAD in the late spring. In agreement with Hulse et al. (2001), juveniles had relatively steady activity pattern across all the months (Fig. 4). This is likely related to the rapid growth of juvenile racers (Fitch 1963, Brown and Parker 1984, Rosen 1991) which signifies the high foraging rate of these individuals throughout the year. Hence our data support that the monthly activity patterns of adult Northern Black Racers follow the standard unimodal curve with a breeding season peak but with juvenile activity that was mostly uniform throughout the year.

There was a difference between the sampling periods for which month exhibited the greatest adult activity: May during 2008-2012 and June during 2015-2017 (Fig. 4). Because temperature (Sperry et al. 2008, Sperry et al. 2013) and precipitation/humidity (Daltry et al. 1998, George et al. 2015) are strong determinants of temperate-snake activity, we compared the mean monthly temperature and precipitation levels of May and June between the sampling periods. According to The Pennsylvania State Climatologist, temperatures were similar (May: $2008-2012=16.9^{\circ} \mathrm{C}, 2015-2017=16.7^{\circ} \mathrm{C}$; June: 2008-2012 $=21.8^{\circ} \mathrm{C}, 2015-2017=21.7^{\circ} \mathrm{C}$ ) between sampling periods, but precipitation was different (May: 2008-2012 = $139.80 \mathrm{~mm}, 2015-2017=70.87 \mathrm{~mm}$; June: $2008-2012=71.73 \mathrm{~mm}, 2015-2017=107.78$ $\mathrm{mm}$ ). Thus, the peak month of activity corresponded to the higher precipitation volume. As precipitation differed while temperatures remained constant in May and June for both sampling periods, we suggest that precipitation/ humidity has a more important influence on Northern Black Racer activity. While this has not previously been identified for this species, changes in precipitation/humidity can affect evaporative water loss through the skin which influences the activity pattern of snake (Dmi'el 1972, Cohen 1975). As this assessment is merely correlative, radiotelemetry would improve our ability to determine a causal link between daily weather conditions and movements.

Reproductive information on Northern Black Racers at LEAD was limited by a small sample size. Our data on the timing of gravid females, from May to July, and the number of eggs coincide with those from previous reports (Surface 1906, Conant 1938, Hulse et al. 2001). The independence between estimated clutch size and body size in our population was surprising as other North American Racers consistently exhibit a significant, positive relationship between these variables (Fitch 1963, Brown and Parker 1984, Rosen 1991, Meshaka and Layne 2015), but our findings likely resulted from small sample size. As no gravid females were found following July, it is likely oviposition occurred from late-June to mid-July, in line with Pennsylvania-wide data (Hulse et al. 2001). No egg clutches or young-of-the-year were identified at LEAD, highlighting the weak links in the ontogeny of Northern Black Racers that remain poorly understood.

Northern Black Racers are a dominant grassland species and serve as important predators for practically all animal groups that occupy grasslands. This study demonstrated how grasslands are important to the longterm survival of racer populations but also highlighted the potential role non-grassland habitats have on supporting juveniles indicating the importance of connectivity between disparate habitats for this species. We also found a significant shift towards a younger population following multiple below-average temperature winters suggesting that overwintering mortality plays a critical role in population demographics of racers. Lastly, activity of Northern Black Racers may be linked to higher precipitation, and other stochastic weather events resulting from climate change, although this link remains corollary. Our research provides a strong and first contribution to the understanding of Northern Black Racer life history in south-central Pennsylvania. Additionally, we recom- 
mend that this and other populations should be further assessed through radiotelemetry studies to better understand how this species exploits grasslands and adjacent habitats, as well as expanding our general knowledge of its life history traits.

\section{ACKNOWLEDGEMENTS}

Funding and other resources for this research were provided by the Shippensburg University Graduate Research Grant. We thank also C. Kindlin, S. Pelesky, and M. Miller of the Letterkenny Army Depot Office of Natural Resources for their support in access and materials to the project. We also wish to acknowledge the professional kindnesses of Base Commander Colonel Gregory Gibbons. A special appreciation goes to Joshua Wright for helping with the deployment of coverboards across LEAD and Vladimir Rep for the collection of snake data. We thank several anonymous reviewers for providing us with thoughtful and constructive comments and suggestions which helped us to improve the manuscript.

\section{REFERENCES}

Auffenberg, W. 1955. A reconsideration of the racer, Coluber constrictor, in eastern United States. Tulane Studies In Zoology 2:89-155

Blouin-Demers, G., and P. J. Weatherhead. 2001. An experimental test of the link between foraging, habitat selection and thermoregulation in black rat snakes Elaphe obsoleta obsoleta. Journal of Animal Ecology 70:1006-1013

Brattstrom, B. H. 1965. Body temperatures of reptiles. American Midland Naturalist: 73(2): 376-422

Brennan, L. A., and W. P. Kuvlesky. 2005. North American grassland birds: An unfolding conservation crisis? The Journal of Wildlife Management 69:1-13

Briggs, V. S. 2012. Agonistic behavior of the Mediterranean Gecko Hemidactylus turcicus. Zoological Studies 51:956-965

Brown, W. S., and W. Parker. 1984. Growth, reproduction and demography of the racer, Coluber constrictor mormon, in northern Utah. Pages 13-40 in R. A. Seigel, L. E. Hunt, J. L. Knight, L. Malaret, and N. L. Zuschlag, editors. Vertebrate Ecology and Systematics - A Tribute to Henry S. Fitch, Lawrence, KS.

Burbrink, F. T., F. Fontanella, R. Alexander Pyron, T. J. Guiher, and C. Jimenez. 2008. Phylogeography across a continent: The evolutionary and demographic history of the North American Racer (serpentes: Colubridae: Coluber constrictor). Molecular Phylogenetics and Evolution 47:274-288. 10.1016/j. ympev.2007.10.020.

Carfagno, G. L., and P. J. Weatherhead. 2008. Energetics and space use: Intraspecific and interspecific comparisons of movements and home ranges of two colubrid snakes. Journal of Animal Ecology:416-424

Carfagno, G. L. F., E. J. Heske, and P. J. Weatherhead. 2016. Does mammalian prey abundance explain forest-edge use by snakes? Ecoscience 13:293-297. 10.2980/i1195-6860-13-3-293.1.

Cohen, A. C. 1975 . Some factors affecting water economy in snakes. Comparative Biochemistry and Physiology 51:361-368

Conant, R. 1938. The reptiles of Ohio. The American Midland Naturalist 20:1-200

Dallas, J. W. 2017. Ecology of the Northern Black Racer (Coluber constrictor constrictor) in south-central Pennsylvania. Master's Thesis. University of Shippensburg, Shippensburg, PA.
Daltry, J. C., T. Ross, R. S. Thorpe, and W. Wüster. 1998. Evidence that humidity influences snake activity patterns: A field study of the Malayan pit viper Calloselasma rhodostoma. Ecography 21:25-34

Delis, P. R., C. K. Kindlin, and R. L. Stewart. 2010. The herpetofauna of Letterkenny Army Depot, south-central Pennsylvania: A starting point to the long-term monitoring and management of amphibians and reptiles. Journal of Kansas Herpetology 34:11-16

Dmi'el, R. 1972. Effect of activity and temperature on metabolism and water loss in snakes. American Journal of Physiology-Legacy Content 223:510-516

Ernst, C. H., T. R. Creque, J. M. Orr, T. D. Hartsell, and A. F. Laemmerzahl. 2014. Operating body temperatures in a snake community of northern Virginia. Northeastern Naturalist 21:247-258

Ernst, C. H., T. R. Creque, J. M. Orr, A. F. Laemmerzahl, and T. D. Hartsell. 2016. Characteristics of a snake community in northern Virginia, USA. The Herpetological Bulletin 135:15-23

Fitch, H. S. 1963. Natural history of the racer Coluber constrictor. University of Kansas Publications Museum of Natural History 15:351-468

George, A. D., F. R. Thompson, 3rd, and J. Faaborg. 2015. Isolating weather effects from seasonal activity patterns of a temperate North American colubrid. Oecologia 178:1251-1259. 10.1007/s00442-0153300-z.

Gibbons, J. W., D. E. Scott, T. J. Ryan, K. A. Buhlmann, T. D. Tuberville, B. S. Metts, J. L. Greene, T. Mills, Y. Leiden, and S. Poppy. 2000. The Global Decline of Reptiles, Déjà Vu Amphibians. BioScience 50:653666

Gillingham, J. C., and C. C. Carpenter. 1978. Snake hibernation: Construction of and observations on a man-made hibernaculum (Reptilia, Serpentes). Journal of Herpetology:495-498

Grant, B. W., A. D. Tucker, J. E. Lovich, A. M. Mills, P. M. Dixon, and J. W. Gibbons. 1992. The use of coverboards in estimating patterns of reptile and amphibian biodiversity. Pages 379-403 in R. Siegel and N. Scott, editors. Wildlife 2001. Elsevier Science Publishing Inc., London, England.

Gregory, P. T., and K. N. Tuttle. 2016. Effects of body size and reproductive state on cover use of five species of temperate-zone natricine snakes. Herpetologica 72:64-72

Halliday, W. D., and G. Blouin-Demers. 2015. Efficacy of coverboards for sampling small northern snakes. Herpetology Notes 8:309-314

Halliday, W. D., and G. Blouin-Demers. 2016. Differential fitness in field and forest explains density-independent habitat selection by gartersnakes. Oecologia 181:841-851. 10.1007/s00442-016-3605-6.

Hamilton, W. J., and J. A. Pollack. 1956. The food of some colubrid snakes from Fort Benning, Georgia. Ecology 37:519-526

Harvey, D. S., and P. J. Weatherhead. 2006. Hibernation site selection by eastern massasauga rattlesnakes (Sistrurus catenatus catenatus) near their northern range limit. Journal of Herpetology 40:66-73. 10.1670/89-05a.1.

Hirth, H. F. 1966. Weight changes and mortality of three species of snakes during hibernation. Herpetologica 22:8-12

Howey, C. A. F. 2014. The ecological effects of prescribed fire on the black racer (Coluber constrictor). Ohio University. 
Howey, C. A. F., M. B. Dickinson, and W. M. Roosenburg. 2016. Effects of a landscape disturbance on the habitat use and behavior of the black racer. Copeia 104:853-863. 10.1643/ce-15-373.

Hulse, A. C., C. J. McCoy, and E. J. Censky. 2001. Amphibians and Reptiles of Pennsylvania and the Northeast. Comstock Publishing Associates.

Keren-Rotem, T., A. Bouskila, and E. Geffen. 2006. Ontogenetic habitat shift and risk of cannibalism in the common chameleon (Chamaeleo chamaeleon). Behavioral Ecology and Sociobiology 59:723-731

Kitchell, J. F. 1969. Thermophilic and thermophobic responses of snakes in a thermal gradient. Copeia 1969:189-191

Kjoss, V. A., and J. L. Livaitis. 2001a. Community structure of snakes in a human-dominated landscape. Biological Conservation 98:285-292

Kjoss, V. A., and J. L. Livaitis. 2001b. Comparison of 2 methods to sample snake communities in early successional habitats. Wildlife Society Bulletin 29:153157

Klemens, M. W. 1993. Amphibians and Reptiles of Connecticut and Adjacent Regions. State Geological and Natural History Survey of Connecticut.

Klimstra, W. D. 1959. Foods of the racer, Coluber constrictor, in southern illinois. Copeia 1959:210-214

Klug, P. E., J. Fill, and K. A. With. 2011. Spatial ecology of eastern yellow-bellied racer (Coluber constrictor flaviventris) and great plains rat snake (Pantherophis emoryi) in a contiguous tallgrass-prairie landscape. Herpetologica 67:428-439. 10.1655/herpetologica-d-10-00076.1.

Martino, J. A., R. G. Poulin, D. L. Parker, and C. M. Somers. 2012. Habitat selection by grassland snakes at northern range limits: Implications for conservation. The Journal of Wildlife Management 76:759767. 10.1002/jwmg.313.

Meshaka Jr, W. E., and P. R. Delis. 2014. Snake assemblage structures and seasonal activity patterns on a military base in southcentral Pennsylvania: Land management implications for snake conservation. The Journal of North American Herpetology 1:7-20

Meshaka Jr, W. E., and J. N. Layne. 2015. The herpetology of southern Florida. Herpetological Conservation and Biology 9:1-353

Meshaka Jr, W. M., S. D. Marshall, T. J. Guiher, and L. Zemba. 2009. Grassland snake assemblages in central and western Pennsylvania and northeastern Ohio, USA. Herpetological Bulletin 110:8-19

Mitchell, J. C. 1994. The Reptiles of Virginia. Smithsonian Institution Press, Washington DC.

Palmer, W. M. 1995. Reptiles of North Carolina. Univ of North Carolina Press.

Plummer, M. V., and J. D. Congdon. 1996. Rates of metabolism and water flux in free-ranging racers, Coluber constrictor. Copeia: 8-14

Powell, R., R. Conant, and J. T. Collins. 2016. Peterson Field Guide to Reptiles and Amphibians of Eastern and Central North America, Fourth Edition. Houghton Mifflin Harcourt.

R Development Core Team. 2019. R: a language and environment for statistical computing. R Foundation for Statistical Computing, Vienna. https://www.R-project.org/.

Rainwater, T. R., K. E. Rainwater, A. C. Murphy, and S. G. Platt. 2007. Coluber constrictor mormon (western yellow-bellied racer) cannibalism. Herpetological Review 38:204
Ratajczak, Z., J. B. Nippert, and S. L. Collins. 2012 Woody encroachment decreases diversity across North American grasslands and savannas. Ecology 93:697-703

Rosen, P. C. 1991. Comparative ecology and life history of the racer (Coluber constrictor) in Michigan. Copeia 1991:897-909

Rosenberg, K. V., A. M. Dokter, P. J. Blancher, J. R. Sauer, A. C. Smith, P. A. Smith, J. C. Stanton, A. Panjabi, L. Helft, and M. Parr. 2019. Decline of the North American avifauna. Science 366:120-124

Row, J. R., and G. Blouin-Demers. 2006. Thermal quality influences effectiveness of thermoregulation, habitat use, and behaviour in milk snakes. Oecologia 148:1-11. 10.1007/s00442-005-0350-7.

Sánchez-Bayo, F., and K. A. G. Wyckhuys. 2019. Worldwide decline of the entomofauna: A review of its drivers. Biological Conservation 232:8-27. 10.1016/j. biocon.2019.01.020.

Shine, R., and R. T. Mason. 2004. Patterns of mortality in a cold-climate population of garter snakes (Thamnophis sirtalis parietalis). Biological Conservation 120:201-210. 10.1016/j.biocon.2004.02.014.

Sperry, J. H., R. G. Peak, D. A. Cimprich, and P. J. Weatherhead. 2008. Snake activity affects seasonal variation in nest predation risk for birds. Journal of Avian Biology 39:379-383

Sperry, J. H., M. P. Ward, and P. J. Weatherhead. 2013. Effects of temperature, moon phase, and prey on nocturnal activity in ratsnakes: An automated telemetry study. Journal of Herpetology 47:105-111. 10.1670/11-325

Stamps, J. A. 1983. The relationship between ontogenetic habitat shifts, competition and predator avoidance in a juvenile lizard (Anolis aeneus). Behavioral Ecology and Sociobiology 12:19-33

Surface, H. A. 1906. The serpents of Pennsylvania. Pennsylvania Department of Agriculture Monthly Bulletin of the Division of Zoology 4:113-201

The Pennsylvania State Climatologist. 2020. Divisional Climate Data for Region 4. Available online at https://climate.met.psu.edu/data/state/regional. php\#division4. Accessed 20 May 2020.

Todd, B. D., J. D. Willson, and J. W. Gibbons. 2010. The global status of reptiles and causes of their decline. Pages 47-67 in D. Sparling, G. Linder, C. Bishop, and S. Krest, editors. Ecotoxicology of Amphibians and Reptiles. SETAC Press, Pensacola, FL.

Tully, T., J. F. Le Galliard, and J. P. Baron. 2020. Micro-geographic shift between negligible and actuarial senescence in a wild snake. Journal of Animal Ecology 89:2704-2716. 10.1111/1365-2656.13317.

Wick, A. F., B. A. Geaumont, K. K. Sedivec, and J. R. Hendrickson. 2016. Grassland degradation. Pages 257-276 in J. F. Shroder and R. Sivanpillai, editors. Biological and Environmental Hazards, Risks, and Disasters. Elsevier.

Wilson, J. B., R. K. Peet, J. Dengler, M. Pärtel, and M. Palmer. 2012. Plant species richness: The world records. Journal of Vegetation Science 23:796-802. 10.1111/j.1654-1103.2012.01400.x.

Yahner, R. H. 2003. Terrestrial vertebrates in Pennsylvania: Status and conservation in a changing landscape. Northeastern Naturalist 10:343-360 